\title{
Effect of ximenynic acid on cell cycle arrest and apoptosis and COX-1 in HepG2 cells
}

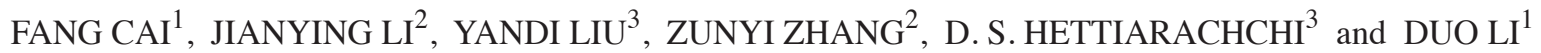 \\ ${ }^{1}$ Department of Food Science and Nutrition, Zhejiang University, Hangzhou, Zhejiang 310058; \\ ${ }^{2}$ Institute of Developmental and Regenerative Biology, Hangzhou Normal University, Hangzhou, Zhejiang 310000, P.R. China; \\ ${ }^{3}$ School of Pharmacy, Curtin Health Innovation Research Institute, Curtin University, Perth 02042G, Australia
}

Received July 16, 2015; Accepted July 22, 2016

DOI: $10.3892 / \mathrm{mmr} .2016 .5920$

\begin{abstract}
Ximenynic acid is a conjugated enyne fatty acid, which is currently of interest due to its anti-inflammatory activity. Due to the association between inflammation and cancer, the present study was designed to investigate the anti-cancer activity of ximenynic acid in the HepG2 human hepatoma cell line and the underlying mechanisms. The current study demonstrated the anti-proliferation and pro-apoptosis activities of ximenynic acid by cell viability assay and flow cytometry analysis. The expression of anti-apoptosis protein silent information regulator T1 (SIRT1) was significantly suppressed by ximenynic acid. Furthermore, ximenynic acid blocked $\mathrm{G} 1 / \mathrm{S}$ phase transition by inhibiting the protein expression of the cell cycle-associated protein general control of amino acid synthesis yeast homolog like 2 (GCN5L2), and the mRNA expression of cyclin D3 and cyclin E1. Furthermore, ximenynic acid suppressed the expression of angiogenesis-associated genes, including vascular endothelial growth factor (VEGF)-B and VEGF-C. Finally, ximenynic acid significantly inhibited the expression of cyclooxygenase-1 (COX-1) mRNA and protein, however COX-2 expression was not reduced. The results of the present study suggested that ximenynic acid may inhibit growth of HepG 2 cells by selective inhibition of COX-1 expression, which leads to cell cycle arrest, and alters the apoptosis pathway and expression of angiogenic factors. The current study aimed to investigate whether ximenynic acid might be developed as novel anticancer agent.
\end{abstract}

Correspondence to: Professor Duo Li, Department of Food Science and Nutrition, Zhejiang University, 866 Yuhangtang Road, Hangzhou, Zhejiang 310058, P.R. China

E-mail: duoli@zju.edu.cn

Key words: angiogenesis, cell apoptosis, cell cycle, COX-1, ximenynic acid

\section{Introduction}

Ximenynic acid (also termed santalbic acid) is a conjugated enyne fatty acid that predominantly exists in the seed oil of the Santalaceae, Olacaceae, and Opiliaceae families (1). Previous studies demonstrated that ximenynic acid has antibacterial $(2,3)$, antifungal and anti-inflammatory activities $(3,4)$. Among these properties, the anti-inflammatory activity of ximenynic acid has been widely studied.

The anti-inflammatory activity of ximenynic acid has been reported since the 1980s. Nugteren and Christ-Hazelhof (5) demonstrated that ximenynic acid inhibits the activity of COXs in the sheep vesicular gland microsomes (5). In rat peritoneal leukocytes, ximenynic acid inhibited the phospholipase activity and the production of inflammatory factors, including thromboxane B2, 6-ketoprostaglandin F1 $\alpha$ and leukotriene B4 (4). It was observed that the levels of leukotriene B4, thromboxane B2, prostaglandin F2 $\alpha$ and prostaglandin E2 (PGE2) in the sandalwood seed oil feeding group, which contains a high percentage of ximenynic acid, were significantly lower in rat liver and plasma compared with soybean oil and safflower oil feeding groups after feeding for 8 weeks (6). These reports suggested that ximenynic acid exerts anti-inflammatory activity by affecting the metabolism of arachidonic acid.

Arachidonic acid metabolism pathways, induced by lipoxygenase, cyclooxygenase (COX) and cytochrome P450, are important for regulating the inflammatory response (7), and they generate several eicosanoid products, including leukotrienes and prostanoids, which are closely associated with the inflammatory response. It is established that lipoxygenase, COX and cytochrome P450 are key targets in various pathologies, including pain, cardiovascular disease, inflammation and cancer (7). The eicosanoids metabolism induced by COX has been previously reported to be involved in various types of cancer (8). Most nonsteroidal anti-inflammatory drugs (NSAIDs) are inhibitors of COXs, and they can reduce the risk of cancer, which was supported by preclinical and clinical studies (9). Furthermore, many natural and synthetic acetylenic acids exert inhibitory effects on cancer cells by suppressing key enzymes of the arachidonic acid metabolism pathways (10).

There are two common types of COX: COX-1 and COX-2. Although COX-2 inhibitors for treating cancer have been a 
research focus for many years, suppression of COX-1 was also demonstrated to exhibit anti-cancer properties $(11,12)$, and alter the distribution of cell cycle (13) and effect angiogenesis (14). Furthermore, inhibition of angiogenesis and arrest of the cell cycle in oncocytes may induce cell apoptosis $(15,16)$.

There are few reports that directly demonstrate the anti-cancer activity of ximenynic acid, thus, it was hypothesized that ximenynic acid may have antitumor properties through inhibition of COX activation. The current study investigated the anti-cancer activity of ximenynic acid in HepG2, and analyzed the underlying mechanism through determining its effects on cell cycle, angiogenesis and COXs pathways.

\section{Materials and methods}

Fatty acid preparation. Ximenynic acid was obtained $(99.5 \%$ purity) from the seed oil of Santalum spicatum by low temperature recrystallization, as described previously (17). Oleic acid (Sigma-Aldrich; Merck Millipore, Darmstadt, Germany) was selected as the non-alkynyl-fatty acid control for its similar structure to ximenynic acid. All other chemicals were purchased commercially as analytical grade reagents.

Cell culture and cell treatment. HepG2 human hepatoma cell line was obtained from the Type Culture Collection of the Chinese Academy of Sciences (Shanghai, China). Cells were grown in high glucose Dulbecco's modified Eagle's medium (DMEM; Hyclone; GE Healthcare Life Sciences, Logan, UT, USA) supplemented with $110 \mathrm{mg} / 1$ sodium pyruvate, 4 mM L-glutamine, 10\% fetal bovine serum (Biowest, Nuaillé, France), $10 \mathrm{mM}$ HEPES (Corning Incorporated, Corning, NY, USA), $100 \mathrm{U} / \mathrm{ml}$ penicillin and $0.1 \mathrm{mg} / \mathrm{ml}$ streptomycin at $37^{\circ} \mathrm{C}$ in a humidified incubator with $5 \% \mathrm{CO}_{2}$. The medium was changed every 2 days. Cells were passaged when they reached $70-80 \%$ confluence, and the culture medium was changed 1 day before.

Cells were seeded overnight in standard medium and then change to serum-free medium supplemented with $1 \%$ insulin-transferrin-selenium (ITS; Invitrogen; Thermo Fisher Scientific, Inc., Waltham, MA, USA), $0.1 \mathrm{mg} / \mathrm{ml}$ fatty acid-free bovine serum albumin (BSA; MP Biomedicals, LLC, Santa Ana, CA, USA) for synchronizing cell cycle division. After $24 \mathrm{~h}$ serum starvation, cells were incubated in experimental media for indicated times. The experimental media was DMEM supplemented with $1 \%$ ITS, $0.1 \mathrm{mg} / \mathrm{ml}$ BSA and various concentrations of ximenynic acid or oleic acid with a molar ratio of 4:1 to BSA. Cells treated with medium not containing fatty acids were termed the vehicle control group.

Cell viability assay. Cells were cultured in 96-well plates overnight with $\sim 1500$ cells/well. After serum-starving for $24 \mathrm{~h}$, serum-free medium was removed and ximenynic acid or oleic acid at 25, 50, 100 and $150 \mu \mathrm{M}$ were added to the cells. After $72 \mathrm{~h}$ incubation, the media were replaced with serum-free medium diluted methyl thiazolyl tetrazolium (MTT; Amresco, LLC, Solon, OH, USA) solution $(5 \mathrm{mg} / \mathrm{ml})$ and incubated at $37^{\circ} \mathrm{C}$ for $4 \mathrm{~h}$. Subsequently, MTT medium was removed and the cells were dissolved with dimethyl sulfoxide followed by detection of absorption at $595 \mathrm{~nm}$ with the Bio-Rad iMark
Microplate Absorbance Reader (Bio-Rad Laboratories, Inc., Hercules, CA, USA).

Flow cytometry analysis. Cell cycle distribution was analyzed by propidium iodide (PI) staining. Cells were seeded in the 6-well plates overnight, and then incubated with serum-free media containing 50 or $150 \mu \mathrm{M}$ ximenynic acid or oleic acid for $24 \mathrm{~h}$ and $36 \mathrm{~h}$ following rinsing with phosphate-buffered saline (PBS). The harvested cells were slowly fixed in pre-chilled $70 \%$ ethanol following washing with PBS. The fixed cells were incubated at $-20^{\circ} \mathrm{C}$ overnight. Subsequently to rinsing with PBS, cells were re-suspended with PI solution from the Cell Cycle Staining kit [CCS012; Multi Sciences (Lianke) Biotech Co., Ltd., Hangzhou, China] and incubated in a dark at room temperature for $30 \mathrm{~min}$. Cell cycle distribution was then analyzed using BD FACSCalibur (Becton Dickinson, USA).

Cell apoptosis was analyzed with Annexin V-FITC (fluorescein isothiocyanate) and PI kit (Multisciences, China). Cells were cultured in 6-well plates overnight, and then starved for $24 \mathrm{~h}$ with serum-free medium followed by culture with different concentrations of ximenynic acid or oleic acid for 72 h. The harvested cells were gently rinsed with PBS. Cells were stained with Annexin V-FITC and PI in dark for 15 min. The level of apoptosis was then analyzed by BD FACSCalibur (BD Biosciences, Franklin Lakes, NJ, USA).

Reverse transcription-quantitative polymerase chain reaction (RT-qPCR). Cells were seeded in 6-well plates overnight. After starving for $24 \mathrm{~h}$ with serum-free medium, cells were treated with 50 or $150 \mu \mathrm{M}$ ximenynic acid or oleic acid for 72 h. Total RNA was extracted by HP Total RNA kit (Omega Bio-Tek, Inc., Norcross, GA, USA) according to the manufacturer's protocol, and the RNA concentration was determined using a NanoDrop 2000 (Thermo Fisher Scientific, Inc., Wilmington, DE, USA). RT was performed on total RNA to produce cDNA with using a Transcriptor First Strand cDNA Synthesis kit (Roche Diagnostics, Basel, Switzerland). The expression of genes was analyzed by qPCR. The sequences of primers are presented in Table I. The qPCR analysis was performed using the SsoFast EvaGreen Supermix (Bio-Rad Laboratories, Inc.), according to the manufacturer's protocol, with a CFX96 ${ }^{\mathrm{TM}}$ Real Time PCR Detection System (Bio-Rad Laboratories, Inc.). The qPCR program commenced with initial denaturation at $95^{\circ} \mathrm{C}$ for $30 \mathrm{sec}$ followed by 40 amplification cycles of $95^{\circ} \mathrm{C}$ for $5 \mathrm{sec}$ (denaturation) and $60^{\circ} \mathrm{C}$ for $10 \mathrm{sec}$ (annealing and extension). The melting curve program was from $65^{\circ} \mathrm{C}$ to $95^{\circ} \mathrm{C}$ for $5 \mathrm{sec}$ with an increment rate of $0.5^{\circ} \mathrm{C} / \mathrm{sec}$ (18). The RPLPO gene was used as the reference gene. Data were selected from a minimum of 3 experiments.

Western blot analysis. Cells were cultured in $100 \mathrm{~mm}$ dishes overnight and then starved with serum-free medium for $24 \mathrm{~h}$. After treatment with 50 or $150 \mu \mathrm{M}$ ximenynic acid or oleic acid for $72 \mathrm{~h}$, cells were harvested and proteins were extracted using cell lysis buffer supplemented with phenylmethylsulfonyl fluoride (Beyotime Institute of Biotechnology, Haimen, China). Whole-cell lysates were centrifuged at 20,000 $\mathrm{x} g$ at $4^{\circ} \mathrm{C}$, for $10 \mathrm{~min}$ to collect the supernatant. The protein concentration was determined by bicinchoninic acid protein 

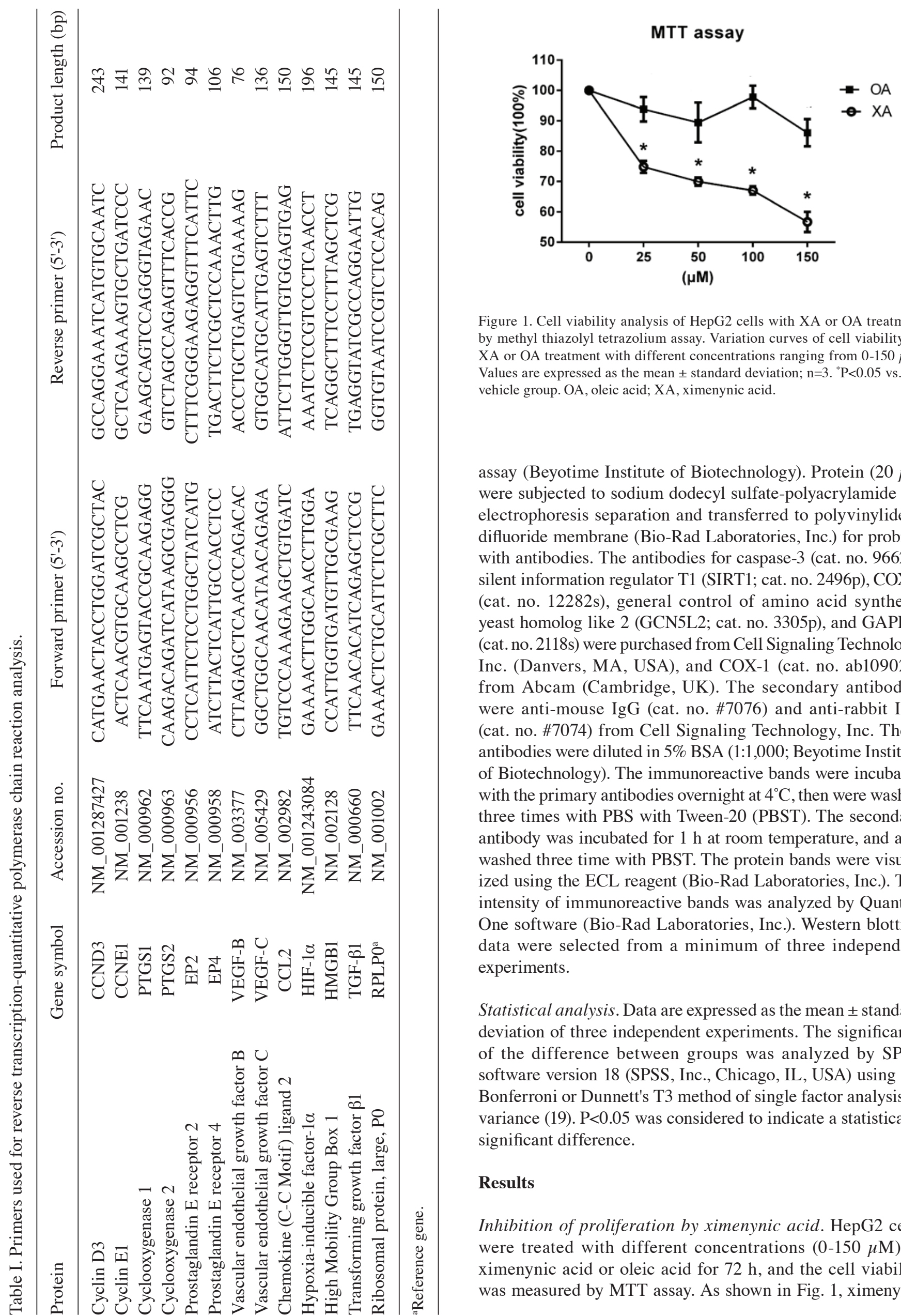

Figure 1. Cell viability analysis of HepG2 cells with XA or OA treatment by methyl thiazolyl tetrazolium assay. Variation curves of cell viability by $\mathrm{XA}$ or OA treatment with different concentrations ranging from $0-150 \mu \mathrm{M}$. Values are expressed as the mean \pm standard deviation; $n=3$. ${ }^{*} \mathrm{P}<0.05$ vs. the vehicle group. OA, oleic acid; XA, ximenynic acid.

assay (Beyotime Institute of Biotechnology). Protein (20 $\mu \mathrm{g})$ were subjected to sodium dodecyl sulfate-polyacrylamide gel electrophoresis separation and transferred to polyvinylidene difluoride membrane (Bio-Rad Laboratories, Inc.) for probing with antibodies. The antibodies for caspase-3 (cat. no. 9662s), silent information regulator T1 (SIRT1; cat. no. 2496p), COX-2 (cat. no. 12282s), general control of amino acid synthesis yeast homolog like 2 (GCN5L2; cat. no. 3305p), and GAPDH (cat. no. 2118s) were purchased from Cell Signaling Technology, Inc. (Danvers, MA, USA), and COX-1 (cat. no. ab109025) from Abcam (Cambridge, UK). The secondary antibodies were anti-mouse IgG (cat. no. \#7076) and anti-rabbit IgG (cat. no. \#7074) from Cell Signaling Technology, Inc. These antibodies were diluted in 5\% BSA (1:1,000; Beyotime Institute of Biotechnology). The immunoreactive bands were incubated with the primary antibodies overnight at $4^{\circ} \mathrm{C}$, then were washed three times with PBS with Tween-20 (PBST). The secondary antibody was incubated for $1 \mathrm{~h}$ at room temperature, and also washed three time with PBST. The protein bands were visualized using the ECL reagent (Bio-Rad Laboratories, Inc.). The intensity of immunoreactive bands was analyzed by Quantity One software (Bio-Rad Laboratories, Inc.). Western blotting data were selected from a minimum of three independent experiments.

Statistical analysis. Data are expressed as the mean \pm standard deviation of three independent experiments. The significance of the difference between groups was analyzed by SPSS software version 18 (SPSS, Inc., Chicago, IL, USA) using the Bonferroni or Dunnett's T3 method of single factor analysis of variance (19). $\mathrm{P}<0.05$ was considered to indicate a statistically significant difference.

\section{Results}

Inhibition of proliferation by ximenynic acid. $\mathrm{HepG} 2$ cells were treated with different concentrations $(0-150 \mu \mathrm{M})$ of ximenynic acid or oleic acid for $72 \mathrm{~h}$, and the cell viability was measured by MTT assay. As shown in Fig. 1, ximenynic 
A
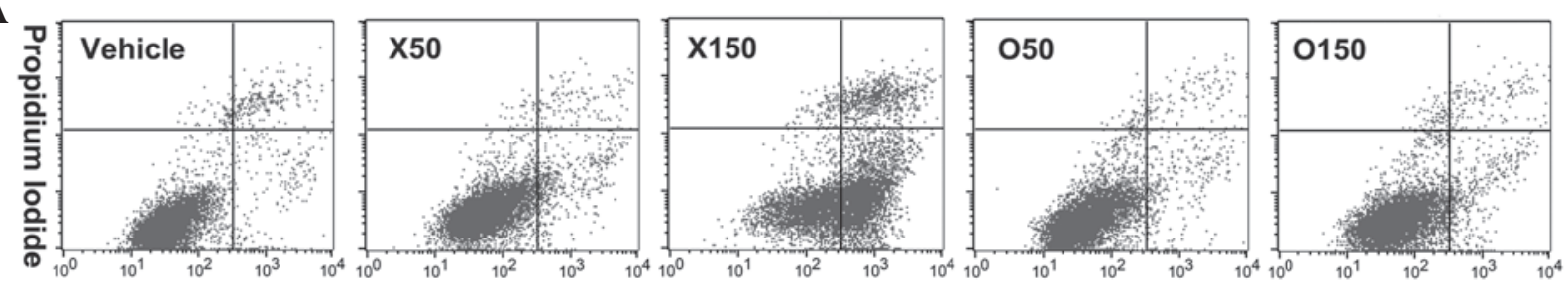

B

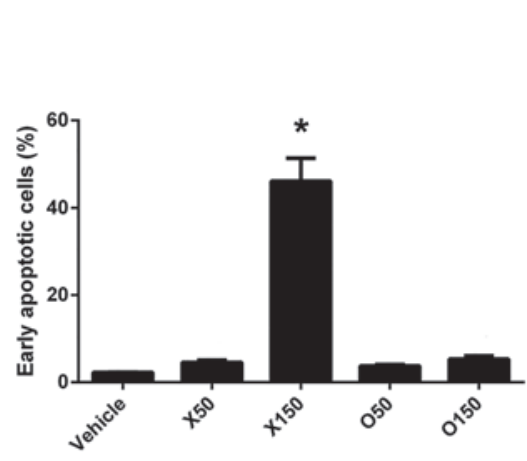

C

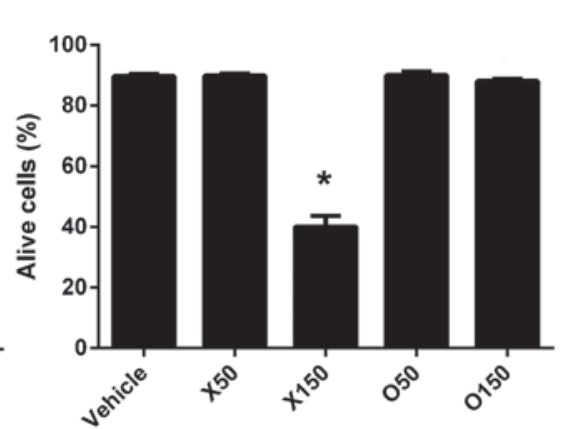

D Vehicle $\quad \times 50 \quad \times 150 \quad 050 \quad 0150$
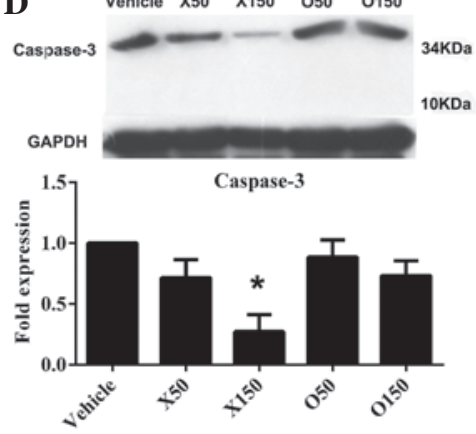

Figure 2. Ximenynic acid induced apoptosis of HepG2 cells. (A) Cell apoptosis analysis of HepG2 cells treated with ximenynic acid or oleic acid at different concentrations by flow cytometry. (B) Levels of early apoptosis cells in the different groups. (C) Levels of alive cells in the different groups. (D) Caspase-3 protein expression in different groups. O50 and O150 groups were treated with oleic acid at 50 and $150 \mu \mathrm{M}$, respectively. X50 and X150 groups were treated with ximenynic acid at 50 and $150 \mu \mathrm{M}$, respectively. Values are expressed as the means \pm standard deviation; $\mathrm{n}=3$. "P<0.05 vs. the vehicle group.

acid significantly inhibited the growth of HepG2 cells from 0 to $150 \mu \mathrm{M}$ in a dose-dependent manner compared with the control group $(\mathrm{P}=0.12,25 \mu \mathrm{M} ; \mathrm{P}=0.04,50 \mu \mathrm{M} ; \mathrm{P}=0.03$, $100 \mu \mathrm{M} ; \mathrm{P}=0.12,150 \mu \mathrm{M})$, while oleic acid could not inhibit HepG 2 cell growth at every concentration compared with the control group (Fig. 1).

Induction of HepG2 apoptosis and caspase-3 activation by ximenynic acid. Considering the anti-proliferation activity of ximenynic acid demonstrated in Fig. 1, it was suspected that ximenynic acid may also lead to apoptosis of HepG2 cells Thus, the HepG2 cells were treated with ximenynic acid or oleic acid (50 and $150 \mu \mathrm{M}$ ) for $72 \mathrm{~h}$ followed by PI staining and flow cytometry analysis (Fig. 2A). It was observed that the percentage of apoptotic cells was significantly increased by ximenynic acid at a concentration of $150 \mu \mathrm{M}$ in a dose-dependent manner ( $\mathrm{P}=0.018$; Fig. $2 \mathrm{~B}$ ), and accordingly the percentage of live cells was significantly reduced at the same concentration $(\mathrm{P}=0.004$; Fig. $2 \mathrm{C})$ compared with the vehicle control group. In the oleic acid group, the percentage of apoptotic cells and living cells was not significantly different compared with the control group (Fig. 2B and C). The anti-cancer activity of $150 \mu \mathrm{M}$ ximenynic acid was greater than that of oleic acid.

The degradation of pro-caspase-3 protein occurs during the process of cell apoptosis, which results in protein cleavage into several fragments (20) and indirectly induces a decrease in the pro-protein. The cleaved caspase-3 (17 KDa) was not detected in the ximenynic acid group, however western blot analysis demonstrated that the level of pro-caspase- 3 (35 KDa) was significantly decreased by $150 \mu \mathrm{M}$ ximenynic acid compared with the vehicle control $(\mathrm{P}=0.001, \mathrm{P}<0.05$; Fig. 2D). Together, flow cytometry and western blot analyses indicated that ximenynic acid promotes apoptosis of HepG2

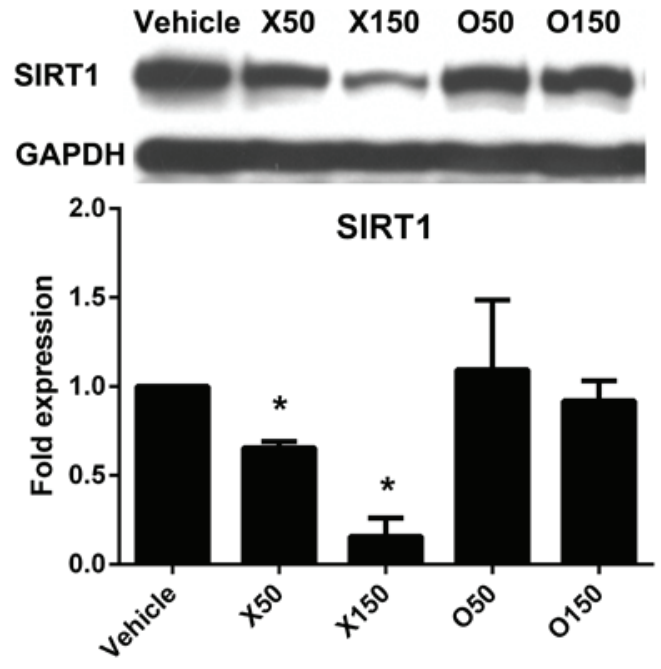

Figure 3. The expression of fold change of SIRT1 protein in HepG2 cells following fatty acids treatment. Cells were incubated with ximenynic acid or oleic acid at two concentrations (50 and $150 \mu \mathrm{M})$ and with vehicle medium for $72 \mathrm{~h}$. O50 and $\mathrm{O} 150$ groups were treated with oleic acid at 50 and $150 \mu \mathrm{M}$, respectively. X50 and X150 groups were treated with ximenynic acid at 50 and $150 \mu \mathrm{M}$, respectively. Data are presented as the mean \pm standard deviation; $\mathrm{n}=3$. ${ }^{*} \mathrm{P}<0.05$ vs. the vehicle group. SIRT1, silent information regulator T1.

cells in a dose-dependent manner, and was more effective than oleic acid.

Effect of ximenynic acid on SIRT1 protein expression. The upstream signals that mediate the effect of ximenynic acid on apoptosis remain unclear. SIRT1 is a NAD-dependent deacetylase that inhibits apoptosis by downregulating transcriptional activity of p53 (21). In addition, SIRT1 silencing induces activation of caspase-3, indicating it is a downstream target of SIRT1 (22). The current study demonstrated that SIRT1 
A

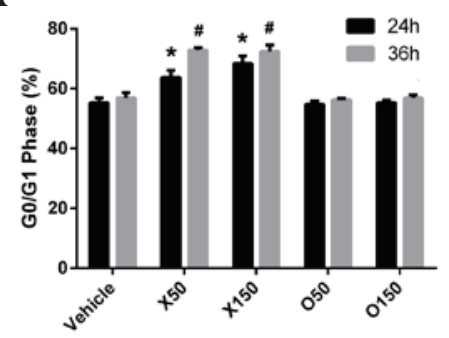

D

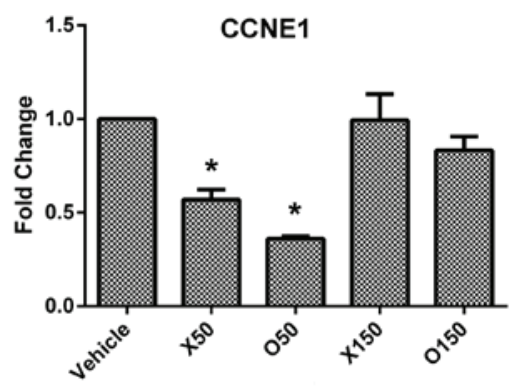

B

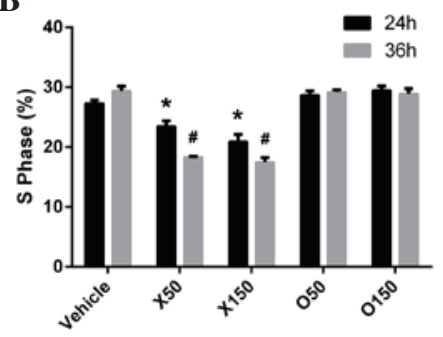

E
C

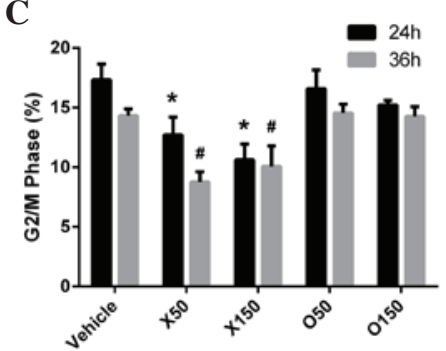

F
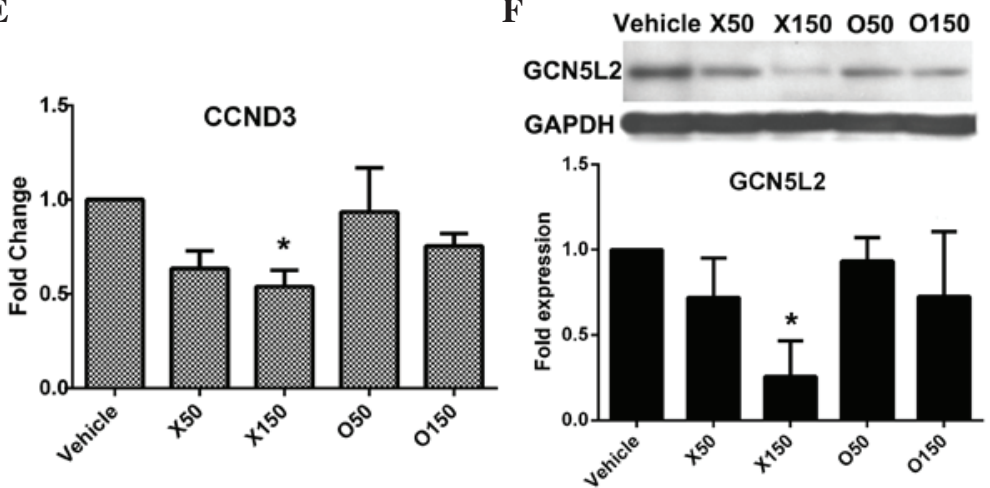

Figure 4. The effects of ximenynic acid or oleic acid treatment on cell cycle distribution and expression of cell cycle related genes and protein. Flow cytometry analysis of HepG2 cells treated with vehicle, ximenynic acid or oleic acid by staining with propidium iodide. Variations of cell cycle distributions in the (A) G0/G1, (B) S, and (C) G2/M phases were determined. Expression fold changes of (D) CCNE1 and (E) CCND3 mRNA after 36 h fatty acid treatment were measured by reverse transcription-polymerase chain reaction. (F) Differential expression of GCN5L2 protein in different fatty acids treatment groups were determined by western blot analysis. O50 and O150 groups were treated with oleic acid at 50 and $150 \mu \mathrm{M}$, respectively. X50 and X150 groups were treated with ximenynic acid at 50 and $150 \mu \mathrm{M}$, respectively. Data are presented as the mean \pm standard deviation; $\mathrm{n}=3$. ${ }^{*} \mathrm{P}<0.05 \mathrm{vs}$. the $24 \mathrm{~h}$ vehicle group; ${ }^{\sharp} \mathrm{P}<0.05 \mathrm{vs}$. the 36 h vehicle group. CCNE1, cyclin E1; CCND3, cyclin D3; GCN5L2, general control of amino acid synthesis yeast homolog like 2.

protein expression was significantly reduced by $150 \mu \mathrm{M}$ ximenynic acid compared with the vehicle control group $(\mathrm{P}=0.013$, $50 \mu \mathrm{M} ; \mathrm{P}=0.019,150 \mu \mathrm{M})$, whereas there was no significant difference in the oleic acid groups compared with vehicle (Fig. 3). These results indicate that ximenynic acid-induced apoptosis is associated with SIRT1 inhibition in HepG2 cells.

Cell cycle changes and expression variation of cell cycle-associated genes and proteins in HepG2 cells. Cell cycle arrest in G1/S transition can induce cancer cell apoptosis (16). The current study investigated whether ximenynic acid affects the cell cycle distribution. After treatment with ximenynic acid for 24 or $36 \mathrm{~h}$, the cell cycle distributions of HepG2 cells were observably changed (Fig. 4A-C). The percentage of cells in G0/G1 phase was significantly increased in the ximenynic acid groups $(\mathrm{P}=0.002,24 \mathrm{~h}, 50 \mu \mathrm{M} ; \mathrm{P}=0.001,24 \mathrm{~h}, 150 \mu \mathrm{M}$; $\mathrm{P}=0.001,36 \mathrm{~h}, 50 \mu \mathrm{M} ; \mathrm{P}=0.001,36 \mathrm{~h}, 150 \mu \mathrm{M}$; Fig. 4A), and significantly decreased in $\mathrm{S}$ phase $(\mathrm{P}=0.002,24 \mathrm{~h}, 50 \mu \mathrm{M}$; $\mathrm{P}=0.001,24 \mathrm{~h}, 150 \mu \mathrm{M} ; \mathrm{P}=0.001,36 \mathrm{~h}, 50 \mu \mathrm{M} ; \mathrm{P}=0.001,36 \mathrm{~h}$, $150 \mu \mathrm{M}$; Fig. 4B) and $\mathrm{G} 2 / \mathrm{M}$ phase $(\mathrm{P}=0.014,24 \mathrm{~h}, 50 \mu \mathrm{M}$; $\mathrm{P}=0.001,24 \mathrm{~h}, 150 \mu \mathrm{M} ; \mathrm{P}=0.001,36 \mathrm{~h}, 50 \mu \mathrm{M} ; \mathrm{P}=0.005,36 \mathrm{~h}$, $150 \mu \mathrm{M}$; Fig. 4C) compared with the vehicle control group in a dose- and time-dependent manner. The structures of ximenynic acid and oleic acid are similar, however, oleic acid did not observably alter the cell cycle distributions of HepG2 cells at 50 or $150 \mu \mathrm{M}$ (Fig. 4A-C). These results indicate that ximenynic acid change the cell cycle distribution of HepG2 cells depending on the dose and duration of ximenynic acid treatment.
To understand whether ximenynic acid affects the expression of cell cycle-associated genes in HepG2 cells, qPCR analysis was performed to determine the expression variation of cyclin genes, including cyclin E1 (CCNE1) and cyclin D3 (CCND3). After treatment for $36 \mathrm{~h}$, the mRNA levels of $C C N E 1$ and $C C N D 3$ were significantly decreased in the 50 and $150 \mu \mathrm{M}$ ximenynic acid group compared with the vehicle control group (CCNE1, $\mathrm{P}=0.001$; CCND3, $\mathrm{P}=0.043$; Fig. 4D and E), and its inhibitory effect on $C C N D 3$ and $C C N E 1$ was stronger than oleic acid.

GCN5L2 (also termed lysine acetyltransferase 2A) is a typical histone acetyltransferase (HAT), which promotes cell cycle progression by acetylation and deacetylation of histones (23). The expression of GCN5L2 protein was significantly downregulated in the $150 \mu \mathrm{M}$ ximenynic acid group compared with the vehicle control group $(\mathrm{P}=0.026$; Fig. 4F).

Effect of ximenynic acid on cyclooxygenase pathway. COX-1 and COX-2 mRNA and protein were demonstrated to be expressed in the HepG2 cells (Fig. 5). After serum starvation for $24 \mathrm{~h}$, HepG2 cells were incubated with fatty acids for 72 h. Although COX-2 protein expression was significantly increased in oleic acid group at $50 \mu \mathrm{M}(\mathrm{P}=0.01, \mathrm{P}<0.05)$, it was not changed in the ximenynic acid group compared with the vehicle control group (Fig. 5A). These results were largely in keeping with the COX-2 gene expression of PTGS2 [prostaglandin-endoperoxide synthase 2 (PTGS2)] in HepG2 (Fig. 5C). 
A

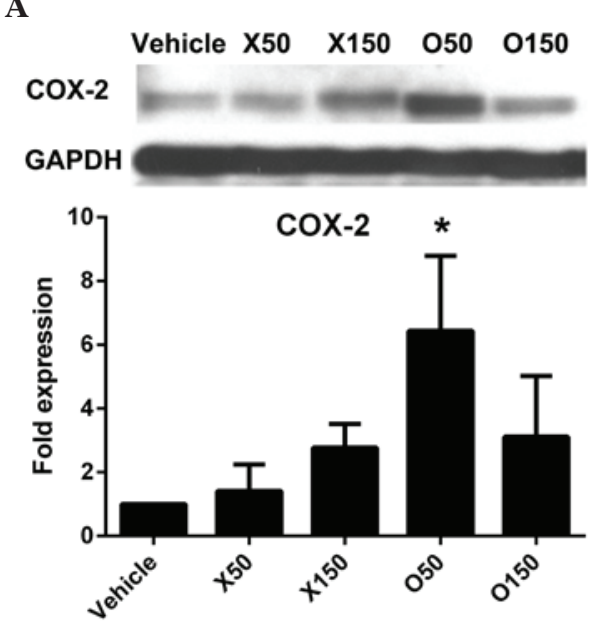

C

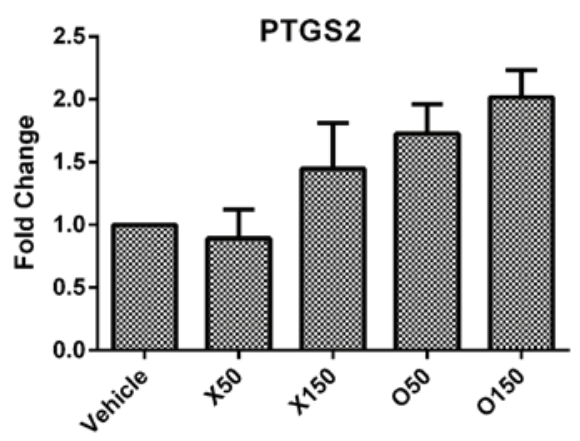

$\mathbf{E}$

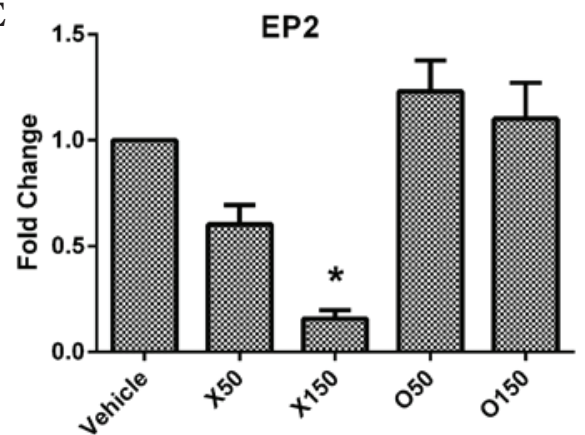

B
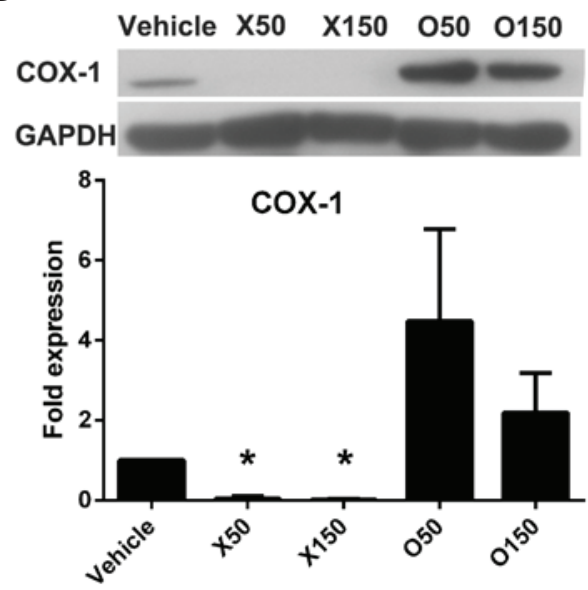

D

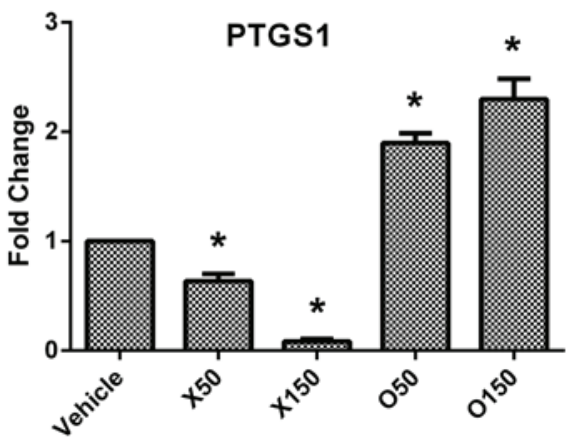

F

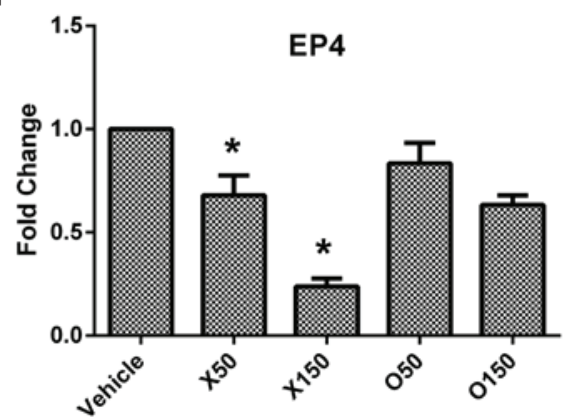

Figure 5. Influence of ximenynic acid or oleic acid treatments on the cyclooxygenase pathway. (A) PTGS2 and (B) PTGS1 mRNA expression levels in different treatment groups. (C) COX-1 and (D) COX-2 proteins expression levels in different treatment groups. (E) EP2 and (F) EP4 mRNA expression levels in different groups. $\mathrm{O} 50$ and $\mathrm{O} 150$ groups were treated with oleic acid at 50 and $150 \mu \mathrm{M}$, respectively. X50 and X150 groups were treated with ximenynic acid at 50 and $150 \mu \mathrm{M}$, respectively. Data are presented as the mean \pm standard deviation; $\mathrm{n}=3$. ${ }^{*} \mathrm{P}<0.05$ vs. the vehicle group. COX, cyclooxygenase; $P T G S$, prostaglandin-endoperoxide synthase; $E P$, prostaglandin E receptor.

Unexpectedly, compared with COX-2, ximenynic acid exerted a greater effect on COX-1, with PTGSI mRNA $(\mathrm{P}=0.009,50 \mu \mathrm{M} ; \mathrm{P}=0.001,150 \mu \mathrm{M}$; Fig. 5D) and COX-1 protein $(\mathrm{P}=0.005,50 \mu \mathrm{M} ; \mathrm{P}=0.001,150 \mu \mathrm{M}$; Fig. 5B) levels significantly decreased by 50 to $150 \mu \mathrm{M}$ ximenynic acid compared with the vehicle control group, whereas PTGSI levels were significantly increased by oleic acid treatment at the concentrations of 50 and $150 \mu \mathrm{M}(\mathrm{P}=0.001,50 \mu \mathrm{M} ; \mathrm{P}=0.001$, $150 \mu \mathrm{M}$; Fig. 5D). These results indicate that ximenynic acid selectively inhibits COX-1 expression.

PGE2 is the product of arachidonic acid metabolism by COXs (24). Prostaglandin E receptor 2 (EP2) a prostaglandin E receptor 4 (EP4) are PGE2 receptors involved in various physiological and pathophysiological processes (25). $E P 2$ and EP4 mRNAs were significantly downregulated in the $150 \mu \mathrm{M}$ ximenynic acid group compared with the vehicle control $(E P 2, \mathrm{P}=0.03 ; E P 4, \mathrm{P}=0.001)$, while they were unchanged by oleic acid (Fig. $5 \mathrm{E}$ and F). It was indicated that the inhibitory effect of ximenynic acid on EP2 and EP4 mRNA levels was more effective than that of oleic acid.

Effect of ximenynic acid on angiogenesis pathways. Vascular endothelial growth factor (VEGF)-B and VEGF-C are two members of the VEGF family that induce angiogenesis and inhibit apoptosis (26). The VEGF-B and VEGF-C mRNA levels were significantly decreased in the 50 and $150 \mu \mathrm{M}$ 
A

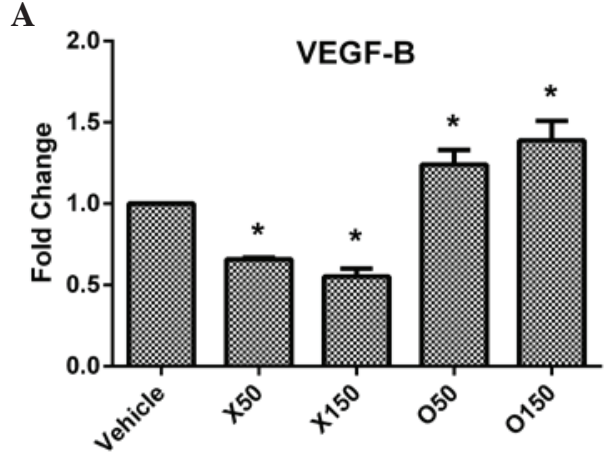

C

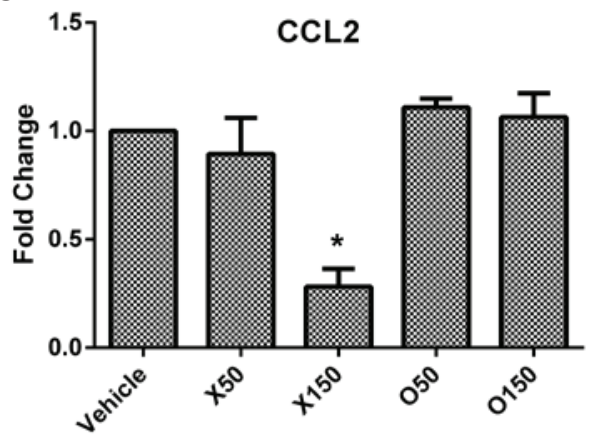

$\mathbf{E}$

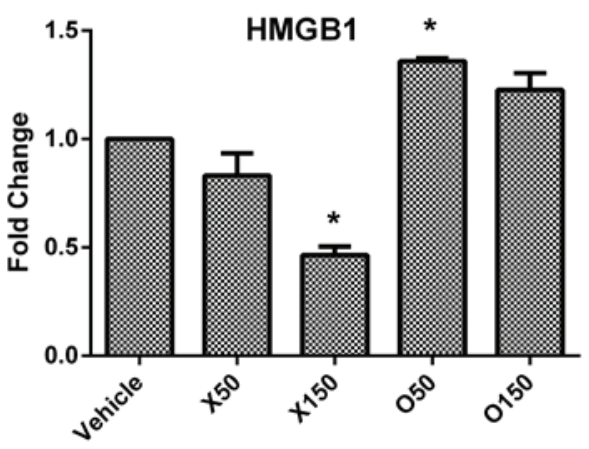

B

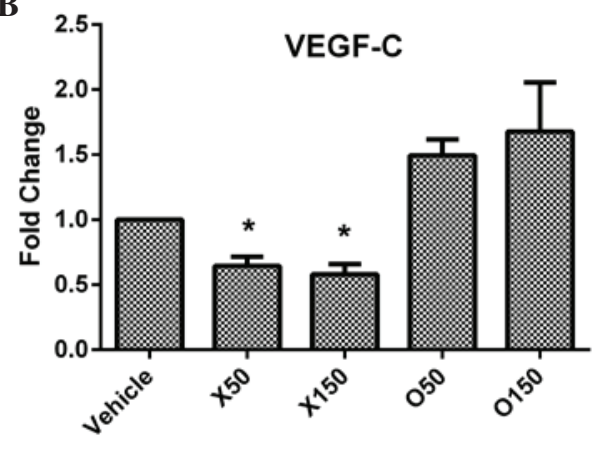

D
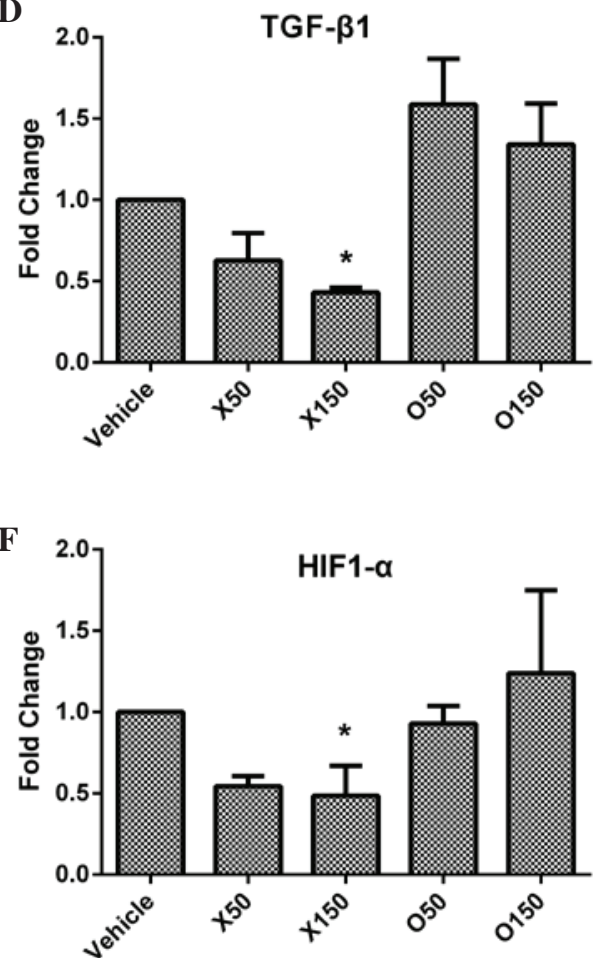

Figure 6. Expression variations of angiogenesis-associated genes in HepG2 cells following fatty acids treatment. Following incubation with ximenynic acid or oleic acid for $72 \mathrm{~h}$, the expression of angiogenesis-associated genes including (A) $V E G F-B$, (B) $V E G F-C$, (C) $C C L 2,(\mathrm{D}) T G F-\beta 1$, (E) $H M G B 1$ and (F) $H I F-1 \alpha$ were analysed by reverse transcription-polymerase chain reaction. O50 and O150 groups were treated with oleic acid at 50 and $150 \mu \mathrm{M}$, respectively. X50 and $\mathrm{X} 150$ groups were treated with ximenynic acid at 50 and $150 \mu \mathrm{M}$, respectively. Data are presented as the mean \pm standard deviation; $\mathrm{n}=3$. ${ }^{*} \mathrm{P}<0.05 \mathrm{vs}$. the vehicle group. VEGF, vascular endothelial growth factor; CCL2, chemokine (C-C motif) ligand 2; TGF- $\beta 1$, transforming growth factor- $\beta 1$; HMGB1, high mobility group box 1 ; HIF-1 $\alpha$, hypoxia inducible factor- $1 \alpha$.

ximenynic acid groups compared with the vehicle control group $(\mathrm{P}<0.05)$ and oleic acid $(\mathrm{P}<0.05)$ groups $(V E G F-B$ : $\mathrm{P}=0.001,50 \mu \mathrm{M} ; \mathrm{P}=0.001,150 \mu \mathrm{M} ; V E G F-C: \mathrm{P}=0.049$, $50 \mu \mathrm{M} ; \mathrm{P}=0.044,150 \mu \mathrm{M})$, whereas $V E G F-B$ was significantly upregulated in the oleic acid $(\mathrm{P}<0.05)$ groups (Fig. 6A and $\mathrm{B})$.

Numerous factors modulate angiogenesis in cancer. The current study investigated the expression of several angiogenesis-associated genes including chemokine (C-C motif) ligand 2 (CCL2), Hypoxia inducible factor 1, $\alpha$ submit $(H I F-1 \alpha)$, high mobility group box 1 (HMGB1), and transforming growth factor- $\beta 1$ (TGF- $\beta 1)$. CCL2 is recognized for its role in the inflammatory response and modulation of angiogenesis (27). HMGB1, a proinflammatory cytokine, is crucial for inflammation-associated diseases and involved in cell apoptosis and angiogenesis (28). HIF-1 $\alpha$, an oxygen balance regulator, regulates VEGF transcription and is involved in numerous cell functions, including angiogenesis (29). TGF- $\beta 1$, a multifunction factor for cells, has also been previously demonstrated to induce angiogenesis progression (30). In the present study, these four mRNA levels were significantly inhibited by $150 \mu \mathrm{M}$ ximenynic acid compared with the vehicle control group (CCL2, $\mathrm{P}=0.016 ; T G F-\beta 1, \mathrm{P}=0.004 ; H M G B 1$, $\mathrm{P}=0.007$; HIF-1 $\alpha, \mathrm{P}=0.044$; Fig. 6C-F). By contrast, oleic acid acid significantly promoted the expression of $H M G B 1$ genes at $50 \mu \mathrm{M}(\mathrm{P}=0.002)$, however did not show significant effects on $T G F-\beta 1, C C L 2$ and HIF-1 $\alpha$ genes compared with the control group (Fig. 6C-F).

\section{Discussion}

Ximenynic acid is one of main components of sandalwood seed fatty acids, and remains to be fully investigated. Sandalwood 
is widely used in perfume, artwork, furniture and for religious reasons, however, the sandalwood tree is a slow-growing plant and requires decades or even centuries for full growth. For the sustainable development of the sandalwood industry, it the value of the sandalwood seed should be investigated.

Sandalwood seeds are rich in oil, and the main fatty acids of the oil are oleic acid and ximenynic acid. The structure of oleic acid is very similar to ximenynic acid, excluding a triple bond. The anti-inflammatory and anti-cancer properties of oleic acid are inferior compared with ximenynic acid, which suggests that the conjugated enyne structure of ximenynic acid is crucial for the medicinal properties. Thus, ximenynic acid may be the key functional factor of sandalwood seed oil. In addition, numerous acetylenic fatty acids exert important pharmacological functions, including antibacterial (2), anti-inflammatory (5) and anti-cancer (10) activities. Ximenynic acid has been demonstrated to be anti-bacterial (3) and anti-inflammatory (5), whereas the anti-cancer properties remain unclear. In the current study MTT assay and flow cytometry results demonstrated the anti-proliferative and apoptosis-promoting activities of ximenynic acid on HepG2 cells. Western blotting and qPCR analysis revealed the suppressive effect of ximenynic acid on the expression of apoptosis- and angiogenesis-associated factors. These suggest that the anti-cancer activity of ximenynic acid is mediated by regulating cell cycle, apoptosis and angiogenesis pathways.

Ximenynic acid induced G1/G0 phase arrest in HepG2 cells and inhibited the expression of CCND3 and CCNE1 genes, and GCN5L2 protein. G1/G0 phase is the critical stage for DNA replication, therefore, arrest of cancer cells in G1/G0 phase may contribute to inhibition of cancer cell proliferation (31). D type-cyclins (D1, D2, D3) are important for cell cycle progression, inducing the transition from G1 to $\mathrm{S}$ phase (32). It previously demonstrated that downregulation of cyclin D3 was correlated with cell cycle arrest and apoptosis (33). Cyclin E is the key factor of G1/S transition, and overexpression of cyclin E protein can induce tumorigenesis (34) and shorten the cell cycle (35). In addition, GCN5L2 was previously reported to promote G1/S transition and promote the expression of cell cycle-associated factors, including cyclin D3 (23) and cyclin E1 (36). The present study demonstrated that the protein levels of GCN5L2 were reduced by ximenynic acid. This suggests that the anti-cancer activity of ximenynic acid is associated with histone acetylation via downregulation of GCN5L2 that inhibits cyclin expression to arrest cancer cells in $\mathrm{G} 0 / \mathrm{G} 1$ phase.

Ximenynic acid induced HepG2 cell apoptosis and inhibited SIRT1 expression. SIRT1 has been previously reported to inhibit cellular senescence and suppress cell apoptosis (37). Overexpression of SIRT1 affects histone deacetylation and inhibits deacetylation of certain tumor repressor proteins, including p53 (38). The results of the present study demonstrated that ximenynic acid downregulates the expression of SIRT1 in a dose-dependent manner. The progression of cancer is promoted by accumulation of epigenetic and genetic changes (39). Acetylation and methylation are post-translational histone modifications that modulate transcriptional activity, DNA recombination and repair. The results of the present study suggest that the anti-cancer activity of ximenynic acid may be mediated

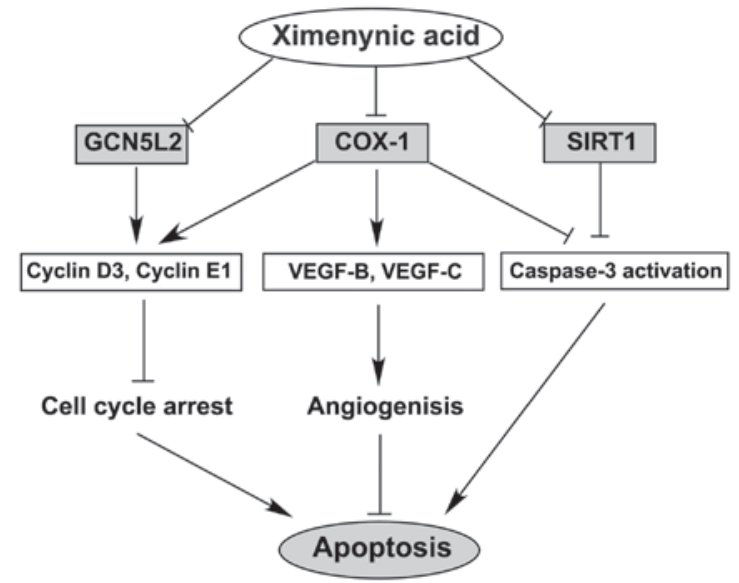

Figure 7. The putative pathways of ximenynic acid-induced anticancer activity. The anticancer activity of ximenynic acid may associate with cell cycle, angiogenesis and cell apoptosis pathways by inhibition of COX-1, GCN5L2 and SIRT1 proteins, and COX-1 may be the key factor of this pathway. GCN5L2, general control of amino acid synthesis yeast homolog like 2; COX,-1 cyclooxygenase; SIRT1, silent information regulator T1; VEGF, vascular endothelial growth factor.

through the deacetylation or methylation of certain critical factors in tumor progression.

Ximenynic acid selectively inhibited COX-1 expression, however it exhibited no effect on COX-2. Typically, ximenynic acid has been previously used for anti-inflammatory treatment and decreases the activity of COXs $(4,5)$. It was previously reported that NSAIDs inhibit cancer cell growth by suppressing COX-2 activity (40), but selective inhibition of COX-1 may achieve the same effect $(11,12)$. As a typical example, aspirin, a COX-1 relative inhibitor, was demonstrated to be beneficial for inhibiting a wide variety of cancers (9). In addition, selective inhibition of COX-1 expression induces apoptosis in certain types of cancer cells (41). The present study demonstrated that ximenynic acid did not alter the COX-2 level, however had resulted in clear inhibition of COX-1 expression. COX-2 was increased following ximenynic acid treatment, however, the expression of COX-1 was reduced. This indicates that ximenynic acid is a selectively inhibits COX-1 expression. Ximenynic acid may suppress angiogenesis of HepG2 cells through inhibition of COX-1 expression. Angiogenesis is involved in de novo generation of blood vessels, and is considered crucial for tumor growth and metastasis (42). Overexpression of COX-1 has previously been demonstrated to promote the expression of angiogenic growth factors (11). In the current study, ximenynic acid suppressed COX-1 protein expression, and inhibited the gene expression of $T G F-\beta 1$, and $H M G B 1$. As a multifunctional cytokine, TGF- $\beta 1$ has previously been revealed to induce angiogenesis (30) and be involved in the progression of angiogenesis induced by COX-1 (43) or HMGB1 (44). In addition, overexpression of HMGB1 has been observed to induce proliferation of cancer cells and angiogenesis (28). Gene and protein expression of HIF-1 $\alpha$ is also affected by HMGB1 (45). This suggests that the anti-cancer activity of ximenynic acid in the HepG 2 cell line may be achieved through inhibiting angiogenic factors.

The anti-cancer activity of ximenynic acid is predominantly attributed to the inhibition of COX-1, which may be 
associated with histone acetylation modification $(46,47)$. A previous report demonstrated that selective inhibition of COX-1 could suppress angiogenesis (14) and induce G0/G1 phase arrest of the cell cycle due to suppression of cyclin $\mathrm{E}$, which is the key protein for G1/S transition (13). Furthermore, inhibition of COX-1 has previously been observed to induce apoptosis and activation of capspase-3 (48). Additionally, ximenynic acid may affect the histone acetylation. The association between COX-1, GCN5L2 and SIRT1 proteins remains unclear, however, the latter two are involved in histone acetylation. In addition, aspirin, a relative COX-1 inhibitor, has an enhanced anti-carcinogenic activity when it was used in combination with a histone deacetylase inhibitor (49). Taken together, the results of the present study indicate that ximenynic acid may regulate the acetylation of histones to exert anti-cancer and anti-inflammatory activities.

The anti-cancer activity of ximenynic acid may be associated with the cell cycle, angiogenesis and cell apoptosis pathways. The putative pathways of ximenynic acid are presented in Fig. 7, and the anti-cancer activity of ximenynic acid may be associated with the suppression of the expression of COX-1, GCN5L2 and SIRT1 proteins, promotion of cell cycle arrest in G0/G1 phase through suppression cell cycle regulatory factors, blocking of angiogenesis by inhibiting the VEGF family, and the acceleration of cell apoptosis via caspase- 3 activation. In summary, ximenynic acid inhibited proliferation and induced apoptosis of HepG2 cells, altered cell cycle distribution and inhibited the expression of angiogenesis-associated factors.

\section{Acknowledgements}

This work was supported by a grant from the National Program on Key Basic Research Project of China (973 Program; grant no. 2015CB553600).

\section{References}

1. Aitzetmuller K: Santalbic acid in the plant kingdom. Plant Syst Evol 298: 1609-1617, 2012.

2. Shawar RM, Humble DJ, Van Dalfsen JM, Stover CK, Hickey MJ, Steele S, Mitscher LA and Baker W: Rapid screening of natural products for antimycobacterial activity by using luciferase-expressing strains of Mycobacterium bovis BCG and Mycobacterium intracellulare. Antimicrob Agents Chemother 41: 570-574, 1997.

3. Jones GP, Rao KS, Tucker DJ, Richardson B, Barnes A and Rivett DE: Antimicrobial activity of santalbic acid from the oil of Santalum-Acuminatum (Quandong). Int J Pharmacogn 33: 120-123, 1995.

4. Croft KD, Beilin LJ and Ford GL: Differential inhibition of thromboxane B2 and leukotriene B4 biosynthesis by two naturally occurring acetylenic fatty acids. Biochim Biophys Acta 921: 621-624, 1987.

5. Nugteren DH and Christ-Hazelhof E: Naturally occurring conjugated octadecatrienoic acids are strong inhibitors of prostaglandin biosynthesis. Prostaglandins 33: 403-417, 1987.

6. Li G, Singh A, Liu Y, Sunderland B and Li D: Comparative effects of sandalwood seed oil on fatty acid profiles and inflammatory factors in rats. Lipids 48: 105-113, 2013.

7. Imig JD and Hammock BD: Soluble epoxide hydrolase as a therapeutic target for cardiovascular diseases. Nat Rev Drug Discov 8: 794-805, 2009.

8. Wang D and Dubois RN: Eicosanoids and cancer. Nat Rev Cancer 10: 181-193, 2010.
9. Rothwell PM, Price JF, Fowkes FG, Zanchetti A, Roncaglioni MC, Tognoni G, Lee R, Belch JF, Wilson M, Mehta Z and Meade TW: Short-term effects of daily aspirin on cancer incidence, mortality, and non-vascular death: Analysis of the time course of risks and benefits in 51 randomised controlled trials. Lancet 379: 1602-1612, 2012.

10. Dembitsky V: Anticancer activity of natural and synthetic acetylenic lipids. Lipids 41: 883-924, 2006.

11. Gupta RA, Tejada LV, Tong BJ, Das SK, Morrow JD, Dey SK and DuBois RN: Cyclooxygenase-1 is overexpressed and promotes angiogenic growth factor production in ovarian cancer. Cancer Res 63: 906-911, 2003.

12. Cho M, Kabir SM, Dong Y, Lee E, Rice VM, Khabele D and Son DS: Aspirin blocks EGF-stimulated cell viability in a COX-1 dependent manner in ovarian cancer cells. J Cancer 4: 671-678, 2013.

13. Wu WK, Sung JJ, Wu YC, Li HT, Yu L, Li ZJ and Cho CH: Inhibition of cyclooxygenase-1 lowers proliferation and induces macroautophagy in colon cancer cells. Biochem Biophys Res Commun 382: 79-84, 2009.

14. Sano H, Noguchi T, Miyajima A, Hashimoto Y and Miyachi H: Anti-angiogenic activity of basic-type, selective cyclooxygenase (COX)-1 inhibitors. Bioorg Med Chem Lett 16: 3068-3072, 2006.

15. Carmeliet P and Jain RK: Angiogenesis in cancer and other diseases. Nature 407: 249-257, 2000.

16. Schwartz GK and Shah MA: Targeting the cell cycle: A new approach to cancer therapy. J Clin Oncol 23: 9408-9421, 2005.

17. Liu YD, Longmore RB and Fox JED: Separation and identification of ximenynic acid isomers in the seed oil of Santalum spicatum $\mathrm{RBr}$ as their 4,4-dimethyloxazoline derivatives. J Am Oil Chem Soc 73: 1729-1731, 1996.

18. Sun G, Zhou Y, Li H, Guo Y, Shan J, Xia M, Li Y, Li S, Long D and Feng L: Over-expression of microRNA-494 up-regulates hypoxia-inducible factor-1 alpha expression via PI3K/Akt pathway and protects against hypoxia-induced apoptosis. J Biomed Sci 20: 100, 2013.

19. Herrmann E, Call J, Hernandez-Lloreda MV, Hare B and Tomasello M: Humans have evolved specialized skills of social cognition: The cultural intelligence hypothesis. Science 317: 1360-1366, 2007.

20. Han Z,Hendrickson EA, BremnerTA and Wyche JH: A sequential two-step mechanism for the production of the mature p17:p12 form of caspase-3 in vitro. J Biol Chem 272: 13432-13436, 1997.

21. Vaziri H, Dessain SK, Ng Eaton E, Imai SI, Frye RA, Pandita TK, Guarente L and Weinberg RA: hSIR2 (SIRT1) functions as an NAD-dependent p53 deacetylase. Cell 107: 149-159, 2001.

22. Ford J, Jiang M and Milner J: Cancer-specific functions of SIRT1 enable human epithelial cancer cell growth and survival. Cancer Res 65: 10457-10463, 2005.

23. Kikuchi H, Takami Y and Nakayama T: GCN5: A supervisor in all-inclusive control of vertebrate cell cycle progression through transcription regulation of various cell cycle-related genes. Gene 347: 83-97, 2005.

24. Williams CS, Mann M and DuBois RN: The role of cyclooxygenases in inflammation, cancer, and development. Oncogene 18: 7908-7916, 1999

25. Regan JW: EP2 and EP4 prostanoid receptor signaling. Life Sci 74: 143-153, 2003.

26. Neufeld G, Cohen T, Gengrinovitch S and Poltorak Z: Vascular endothelial growth factor (VEGF) and its receptors. Faseb J 13: 9-22, 1999.

27. Salcedo R, Ponce ML, Young HA, Wasserman K, Ward JM, Kleinman HK, Oppenheim JJ and Murphy WJ: Human endothelial cells express CCR2 and respond to MCP-1: Direct role of MCP-1 in angiogenesis and tumor progression. Blood 96: 34-40, 2000.

28. Volp K, Brezniceanu ML, Bösser S, Brabletz T, Kirchner T, Göttel D, Joos S and Zörnig M: Increased expression of high mobility group box 1 (HMGB1) is associated with an elevated level of the antiapoptotic c-IAP2 protein in human colon carcinomas. Gut 55: 234-242, 2006.

29. Carmeliet P, Dor Y, Herbert JM, Fukumura D, Brusselmans K, Dewerchin M, Neeman M, Bono F, Abramovitch R, Maxwell P, et al: Role of HIF-1alpha in hypoxia-mediated apoptosis, cell proliferation and tumour angiogenesis. Nature 394: 485-490, 1998.

30. Nakagawa T, Li JH, Garcia G, Mu W, Piek E, Böttinger EP, Chen Y, Zhu HJ, Kang DH, Schreiner GF, et al: TGF-beta induces proangiogenic and antiangiogenic factors via parallel but distinct Smad pathways. Kidney Int 66: 605-613, 2004. 
31. Grana X and Reddy EP: Cell cycle control in mammalian cells: Role of cyclins, cyclin dependent kinases (CDKs), growth suppressor genes and cyclin-dependent kinase inhibitors (CKIs). Oncogene 11: 211-219, 1995.

32. Hunter T and Pines J: Cyclins and cancer. II: Cyclin D and CDK inhibitors come of age. Cell 79: 573-582, 1994

33. Fimognari C, Nüsse M, Berti F, Iori R, Cantelli-Forti G and Hrelia P: Cyclin D3 and p53 mediate sulforaphane-induced cell cycle delay and apoptosis in non-transformed human $\mathrm{T}$ lymphocytes. Cell Mol Life Sci 59: 2004-2012, 2002.

34. Keyomarsi K, Tucker SL, Buchholz TA, Callister M, Ding Y, Hortobagyi GN, Bedrosian I, Knickerbocker C, Toyofuku W, Lowe M, et al: Cyclin E and survival in patients with breast cancer. N Engl J Med 347: 1566-1575, 2002.

35. Ohtsubo M, Theodoras AM, Schumacher J, Roberts JM and Pagano M: Human cyclin E, a nuclear protein essential for the G1-to-S phase transition. Mol Cell Biol 15: 2612-2624, 1995.

36. Chen L, Wei T, Si X, Wang Q, Li Y, Leng Y, Deng A, Chen J, Wang G, Zhu S and Kang J: Lysine acetyltransferase GCN5 potentiates the growth of non-small cell lung cancer via promotion of E2F1, cyclin D1, and cyclin E1 expression. J Biol Chem 288: 14510-14521, 2013.

37. Longo VD and Kennedy BK: Sirtuins in aging and age-related disease. Cell 126: 257-268, 2006.

38. Liu T, Liu PY and Marshall GM: The critical role of the class III histone deacetylase SIRT1 in cancer. Cancer Res 69: 1702-1705, 2009.

39. Baylin SB and Herman JG: DNA hypermethylation in tumorigenesis: Epigenetics joins genetics. Trends Genet 16: 168-174, 2000.

40. Fosslien E: Molecular pathology of cyclooxygenase-2 in neoplasia. Ann Clin Lab Sci 30: 3-21, 2000.

41. Daikoku T, Wang D, Tranguch S, Morrow JD, Orsulic S, DuBois RN and Dey SK: Cyclooxygenase-1 is a potential target for prevention and treatment of ovarian epithelial cancer. Cancer Res 65: 3735-3744, 2005
42. Wu Q, Wang H, Zhao X, Shi Y, Jin M, Wan B, Xu H, Cheng Y, $\mathrm{Ge} \mathrm{H}$ and $\mathrm{Zhang} \mathrm{Y}$ : Identification of G-protein-coupled receptor 120 as a tumor-promoting receptor that induces angiogenesis and migration in human colorectal carcinoma. Oncogene 32: 5541-5550, 2013.

43. Yang DH, Hsu CF, Lin CY, Guo JY, Yu WC and Chang VH Kruppel-like factor 10 upregulates the expression of cyclooxygenase 1 and further modulates angiogenesis in endothelial cell and platelet aggregation in gene-deficient mice. Int J Biochem Cell Biol 45: 419-428, 2013.

44. Pittet JF, Koh H, Fang X, Iles K, Christiaans S, Anjun N, Wagener BM, Park DW, Zmijewski JW, Matthay MA and Roux J: HMGB1 accelerates alveolar epithelial repair via an IL-1 $\beta$ - and $\alpha v \beta 6$ integrin-dependent activation of TGF- $\beta 1$. PloS One 8: e63907, 2013.

45. Kim HY, Park SY, Lee SW, Lee HR, Lee WS, Rhim BY, Hong KW and Kim CD: Inhibition of HMGB1-induced angiogenesis by cilostazol via SIRT1 activation in synovial fibroblasts from rheumatoid arthritis. PloS One 9: e104743, 2014.

46. Taniura S, Kamitani H, Watanabe T and Eling TE: Transcriptional regulation of cyclooxygenase-1 by histone deacetylase inhibitors in normal human astrocyte cells. J Biol Chem 277: 16823-16830, 2002.

47. Omura N, Griffith M, Vincent A, Li A, Hong SM, Walter K, Borges $\mathrm{M}$ and Goggins $\mathrm{M}$ : Cyclooxygenase-deficient pancreatic cancer cells utilize exogenous sources of prostaglandins. Mol Cancer Res 8: 821-832, 2010.

48. Kolaczkowska E, Koziol A, Plytycz B, Arnold B and Opdenakker G: Altered apoptosis of inflammatory neutrophils in MMP-9-deficient mice is due to lower expression and activity of caspase-3. Immunol Lett 126: 73-82, 2009.

49. Son DS, Wilson AJ, Parl AK and Khabele D: The effects of the histone deacetylase inhibitor romidepsin (FK228) are enhanced by aspirin (ASA) in COX-1 positive ovarian cancer cells through augmentation of p21. Cancer Biol Ther 9: 928-935, 2010. 